\title{
PENGARUH E-LEARNING, PEMBELAJARAN LANGSUNG, DAN FAKTOR GAYA KOGNITIF TERHADAP HASIL BELAJAR PRAKARYA KEWIRAUSAHAAN
}

\author{
Fadlul Amin Nudin, Rufi'i* , Djoko Adi Walujo \\ Program Studi Teknologi Pendidikan Pascasarjana, Universitas PGRI Adi Buana Surabaya
}

\section{Edcomtech}

Jurnal Kajian Teknologi

Pendidikan

Volume 6, No 2, Oktober 2021

222-235

DOI: 10.17977/um039v6i12021p222

Submitted 10-05-2020

Accepted 28-12-2020

Corresponding Author*

Fadlul Amin Nudin

Universitas PGRI Adi Buana

Surabaya

Jl. Raya Ngasinan No. 84

Kepatihan, Menganti-Gresik Kode

Pos 61174

Email:

fadlulaminnudin@gmail.com

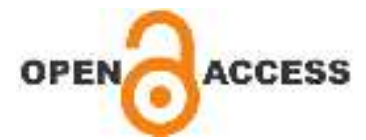

\begin{abstract}
Abstrak
Penelitian ini bertujuan untuk melihat perbedaan hasil belajar prakarya kewirausahaan kelompok pembelajaran berbasis E-Learning dan langsung, melihat perbedaan hasil belajar antara gaya kognitif Field Dependent dan Field Independent, dan melihat interaksi pembelajaran berbasis E-Learning, langsung, dan gaya kognitif terhadap hasil belajar. Penelitian ini menggunakan metode eksperimen semu faktorial $2 \times 2$. Kelompok kontrol menggunakan pembelajaran langsung, sedangkan kelompok eksperimen menggunakan E-Learning. Analisis menggunakan Anova dua arah akan membandingkan pengaruh pembelajaran berbasis E-Learning dan langsung serta gaya kognitif terhadap hasil belajar. Hasil penelitian: Ha. 1 nilai probabilitas $(p)=0,013<0,05$ artinya terdapat perbedaan hasil belajar pembelajaran berbasis E-Learning dan langsung, Ha.2 nilai probabilitas $(p)=0,004<0,05$ artinya terdapat perbedaan hasil belajar antara gaya kognitif Field Dependent dan Field Independent, Ha.3 nilai probabilitas $(p)=0,07>0,05$ artinya tidak terdapat pengaruh antara pembelajaran berbasis E-Learning, langsung, dan gaya kognitif terhadap hasil belajar.
\end{abstract}

Kata Kunci: E-Learning, Gaya Kognitif, Hasil Belajar

\begin{abstract}
This study aims to see differences in learning outcomes of E-Learningbased and direct learning group entrepreneurship learning outcomes, to see differences in learning outcomes between Field Dependent and Field Independent cognitive styles, and to see E-Learning-based learning interactions, direct, and cognitive styles on learning outcomes. This study used a $2 \times 2$ factorial quasi-experimental method. The control group uses direct learning, while the experimental group uses E-Learning. Analysis using two-way ANOVA will compare the effect of direct and E-Learningbased learning and cognitive styles on learning outcomes. Results: Ha.1 probability value $(p)=0.013<0.05$ means that there are differences in learning outcomes based on E-Learning and direct learning, Ha.2 probability value $(p)=0.004<0.05$ means that there are differences in learning outcomes between Field Dependent and Field Independent cognitive style, Ha. 3 probability value $(p)=0.07>0.05$ means that there is no influence between E-Learning-based, direct and cognitive style learning on learning outcomes.
\end{abstract}

Keywords: E-Learning, Cognitive Style, Learning Outcomes 


\section{LATAR BELAKANG}

Salah satu akibat revolusi industri 4.0 di bidang pendidikan adalah pemanfaatan teknologi elektronik dalam proses pembelajaran dengan menerapkan model pembelajaran E-Learning, huruf " $E$ " pada $E$ Learning memiliki arti Electronic, sehingga bisa diartikan E-Learning yaitu kegiatan atau proses pembelajaran dengan memanfaatkan bantuan media elektronik. Hasil dari teknologi elektronik yaitu (1) perangkat keras (hardware) segala sesuatu yang berwujud nyata dan bisa diraba secara langsung, (2) aplikasi atau perangkat lunak (software) berkaitan dengan dunia maya atau digital (menjalankan perintah yang diberikan oleh pengguna aplikasi dan menggunakan bahasa pemrograman atau komputasi), dan (3) internet (menghubungkan antara sistem dan jaringan telekomunikasi yang menghubungkan media elektronik satu sama lain).

Secara teknis internet bertugas menghubungkan antara media elektronik satu sama lain dengan sistem aplikasi sehingga pengguna dapat memanfaatkan sesuai dengan keperluannya. Sebagai contoh siswa menggunakan aplikasi pencarian google chrome, email, youtube dan lainlainya yang terdapat pada HP untuk mencari referensi saat mengerjakan tugas-tugas sekolah termasuk bagian dari pembelajaran berbasis E-Learning.

Pembelajaran berbasis E-Learning membuat siswa belajar untuk mandiri, belajar untuk percaya akan kemampuan diri sendiri, belajar menjadi siswa aktif yang mampu mengelola informasi (mencari dan menyimpulkan) dan menyelesaikan masalahnya secara mandiri. Hal tersebut tentu sangat berbeda jika dibandingkan dengan model pembelajaran Langsung dimana saat kegiatan belajar mengajar guru berperan aktif, guru menjadikan siswa sebagai objek, guru sebagai sumber belajar utama, mengontrol siswa didalam kelas dan secara tidak langsung guru menyamaratakan kemampuan seluruh siswa perlu diperbaiki agar hasil belajar yang didapatkan maksimal.

Adapun maksud penelitian ini yaitu (1) untuk mencari signifikansi perbedaan hasil belajar prakarya kewirausahaan antara kelompok siswa yang menggunakan pembelajaran berbasis E-Learning dengan pembelajaran Langsung, (2) untuk mencari signifikansi perbedaan hasil belajar prakarya kewirausahaan antara kelompok siswa yang memiliki gaya kognitif Field Dependent dan gaya kognitif Field Independent, dan (3) untuk mencari signifikansi interaksi antara penerapan pembelajaran berbasis $E$ Learning dengan pembelajaran Langsung serta gaya kognitif terhadap hasil belajar prakarya kewirausahaan.

\section{Pembelajaran Berbasis E-Learning}

Pembelajaran berbasis E-Learning atau yang sering dikenal dengan istilah WebBased-Education (WBE) adalah proses pembelajaran yang memanfaatkan perkembangan teknologi, informasi, dan komunikasi dengan bantuan aplikasi web pendidikan. Pembelajaran web based learning (E-Learning berdasarkan WEB) memiliki tiga hal utama yaitu pedagogy, materi dan technology (Hadjerrouit, 2010; Zyainuri \& Marpanaji, 2012). Hal tersebut membuat satu sama lain (desain pembelajaran berbasis E-Learning) saling mempengaruhi sehingga pembelajaran berbasis E-Learning meluas menjadi proses pembelajaran yang bersifat dinamis, kolaboratif dan multimedia.

Manfaat Pembelajaran Berbasis E-Learning

Manfaat pembelajaran berbasis $E$ Learning adalah (1) perubahan paradigma pembelajaran konvensional ke arah pembelajaran berbasis teknologi meningkatkan kompetensi dan soft skill guru, menumbuhkan motivasi belajar siswa dan memperkuat pemahaman siswa dalam menerima pembelajaran, (2) cepat, tanpa melihat batas ruang dan waktu (siswa dapat belajar dimanapun dan kapan saja tanpa terfokus pada pertemuan atau tatap muka dikelas karena sudah difasilitasi oleh 
pembelajaran E-Learning), (3) mudah diakses, secara garis besar guru dan siswa dapat memanfaatkan teknologi elektronik untuk mengakses sumber belajar secara online maupun offline (siswa dapat mengunduh dan menyimpan materi belajar dengan format $p d f$ atau $m s$. word tanpa harus mencetak terlebih dahulu), (4) efektif dan efisien dimana teknologi sekarang ini berkembang sangat pesat dan didukung dengan sistem kompleks yang terintegrasi ke seluruh penjuru dunia membuat siswa mudah mencari informasi atau referensi sumber belajar yang seluas-luasnya selama perangkat keras (hardware) terhubung dengan jaringan internet, (5) pengayaan materi pembelajaran sesuai dengan kemajuan teknologi, (6) secara tidak langsung siswa belajar mandiri dan bertanggung jawab terhadap hasil belajar dirinya sendiri, dan (7) biaya internet yang murah dibandingkan membeli buku paket, dan banyak fasilitas yang ditawarkan oleh penyedia jasa internet sangat membantu dalam pembelajaran. Sejalan dengan Pinontoan \& Walean (2020) menyatakan Elearning lebih unggul dalam penerapannya karena mengurangi biaya guru mengajar dan tidak memerlukan kertas pensil lagi, juga memiliki dampak yang lebih baik pada hasil belajar.

\section{Fungsi Pembelajaran Berbasis E-Learning}

Terdapat setidaknya 3 (tiga) fungsi pembelajaran berbasis elektronik dalam kegiatan pembelajaran di kelas (classroom instruction) yaitu sebagai suplemen (bersifat tambahan), komplemen (pelengkap) atau substitusi (menggantikan). Fungsi pembelajaran berbasis elektronik sebagai: (1) bersifat suplemen (pembelajaran dengan maksud pilihan atau opsional. Siswa diberi hak untuk memilih pembelajaran berbasis $E$ Learning atau konvensional); (2) bersifat komplemen (proses pembelajaran berbasis E-Learning dimaksudkan sebagai pelengkap pembelajaran pada saat siswa di kelas); dan (3) bersifat substitusi (proses pembelajaran berbasis elektronik sepenuhnya diterapkan saat proses pembelajaran keseluruhan (Chandrawati, 2010; Karwati, 2014; Sutanta, 2009).

Terdapat 3 (tiga) pilihan pengganti proses pembelajaran yang bisa dipilih oleh siswa, antara lain (1) kegiatan pembelajaran seluruhnya dilakukan dalam tatap muka (umum), (2) beberapa kegiatan pembelajaran dengan tatap muka, sedangkan metode pembelajaran yang lain menggunakan bantuan internet (daring), dan (3) kegiatan pembelajaran seluruhnya dengan internet (daring).

Perancangan kegiatan pembelajaran pada intinya berupa gambaran tentang beberapa aktivitas dan tindakan yang akan dilakukan pada saat berlangsungnya proses pembelajaran. Dengan demikian dapat disimpulkan, aplikasi perencanaan pembelajaran yang berbasis model pembelajaran E-Learning memuat rencana, perkiraan dan gambaran umum kegiatan pembelajaran dengan memanfaatkan jaringan komputer, baik intranet maupun internet.

Lingkup perencanaan pembelajaran meliputi 4 (empat) komponen utama yaitu: tujuan, materi atau bahan ajar, kegiatan belajar mengajar, dan evaluasi. Hal tersebut sesuai dengan pernyataan Hanum (2013) yaitu E-Learning solution/strategy: "An $e$ learning solution of strategy is composed of content, technology, and services. Content includes courses, curriculum, and knowledge or skills development modules. Technology is the method used to deliver the content, including the internet and teleconferencing. Services relate to maintenance, content upgrades, and technical upgrades to both delivery and content. Understanding these components is an important first step to understanding what E-Learning is and how it is "delivered".

Penggunaan model pembelajaran ELearning tidak sebatas pemanfaatan internet saja, namun segala aktivitas belajar yang menggunakan bantuan teknologi elektronik juga termasuk pembelajaran $E$ - 
Learning dan pemanfaatan internet merupakan salah satu contoh. Teknologi elektronik yang banyak digunakan misalnya internet, intranet, tape video atau audio, penyiaran melalui satelit, televisi interaktif serta CD-ROM (Aminoto, 2014; Cahyono, 2015; Rusman, 2012) .

Penggunaan model pembelajaran $E$ Learning mengakibatkan pemahaman siswa tentang sebuah materi tidak tergantung pada guru atau instruktur tetapi juga dapat diperoleh dari media elektronik. Beberapa pendapat diatas dapat disimpulkan bahwa model pembelajaran E-Learning merupakan kegiatan belajar mengajar yang memanfaatkan teknologi khususnya media elektronik seperti HP, laptop, internet, intranet, tape video maupun audio, satelit, tv, $C D-R O M$ dan semua media elektronik yang mendukung dalam kegiatan proses pembelajaran.

\section{Pembelajaran Langsung}

Pembelajaran Langsung adalah pembelajaran secara umumnya yang digunakan karena bersifat teacher centered (guru mempunyai kontrol penuh setiap kegiatan pembelajaran yang ada di kelas guna menciptakan proses belajar yang kondusif). Model pembelajaran Langsung menekankan pada proses tatap muka dimana guru mendemonstrasikan atau menjelaskan pengetahuan dan keterampilan melalui tahapan-tahapan, hal tersebut tentu memerlukan waktu cukup lama. Pembelajaran Langsung membutuhkan perancangan dan implementasi rinci yang berorientasi pada tugas terstruktur. Guru akan selalu mengulang pembelajaran kepada siswa namun siswa juga harus melibatkan diri secara langsung dalam setiap kegiatan pembelajaran.

Model pembelajaran Langsung adalah model pembelajaran yang dirancang khusus untuk menunjang proses belajar siswa yang berkaitan dengan pengetahuan deklaratif dan pengetahuan prosedural yang terstruktur dengan baik yang dapat diajarkan dengan pola kegiatan yang bertahap selangkah demi selangkah. Model pembelajaran langsung (Direct Instruction) dikenal dengan sebutan active teaching, pembelajaran langsung juga dinamakan whole-class teaching (Putri et al., 2019). Sedangkan menurut Santrock dalam Mashudi (2016) perencanaan dan instruksi disusun secara ketat, dan guru mengarahkan pembelajaran siswa. Aktivitas pembelajaran ini menekankan pada paparan atau ceramah, penjelasan dan demonstrasi. Dalam hal ini guru harus menerangkan dan mendemonstrasikan materi yang sebanyakbanyaknya kepada siswa.

\section{Gaya Kognitif}

Gaya kognitif yaitu istilah dalam psikologi kognitif yang digunakan untuk mendefinisikan cara orang berpikir, memahami dan mengingat informasi. Menurut Rufi'i (2011), gaya kognitif dijelaskan seperti apa cara siswa mengelola informasi yang dia terima. Fauzi (2019) juga menyatakan gaya kognitif terlihat dalam variasi individu ketika memperhatikan, mengingat, menunjukkan informasi, serta pikiran berbeda yang ditunjukkan dari kognisi serta kepribadian.

Terdapat 2 (dua) tipe gaya kognitif antara lain gaya kognitif Field Dependent (siswa yang memiliki gaya kognitif Field Dependent berkarakter cenderung bekerja lebih baik apabila diberikan informasi atau bimbingan secara lebih dan lebih mudah dipengaruhi lingkungannya, berbeda dengan gaya kognitif Field Independent (siswa yang memiliki gaya kognitif Field Independent berkarakter didalam melaksanakan tugas atau menyelesaikan suatu soal maka siswa tersebut akan lebih baik jika diberikan kebebasan dan tidak mudah untuk dipengaruhi lingkungan).

Ngilawajan (2013) mendefinisikan jika seseorang memiliki gaya kognitif Field Dependent (FD) yaitu seseorang yang kurang bahkan tidak mampu memilah sebagian sesuatu dari kesatuan dan lebih cepat menerima konteks yang dominan. 
Tabel 1. Karakter Field Dependent dan Field Independent Menurut Garge Dan Guild

\begin{tabular}{|c|c|c|}
\hline Karakter & $\begin{array}{c}\text { Siswa dengan gaya kognitif Field } \\
\text { Dependent }\end{array}$ & $\begin{array}{c}\text { Siswa dengan gaya kognitif } \\
\text { Field Independent }\end{array}$ \\
\hline Cara menyikapi informasi & Secara global & Secara analitis \\
\hline $\begin{array}{l}\text { Cara memahami struktur } \\
\text { informasi }\end{array}$ & $\begin{array}{l}\text { Mendefinisikan tentang informasi } \\
\text { yang masuk ke dalam konsep } \\
\text { global }\end{array}$ & $\begin{array}{l}\text { Mendefinisikan tentang } \\
\text { informasi yang masuk ke } \\
\text { dalam konsep analitis }\end{array}$ \\
\hline $\begin{array}{l}\text { Cara membedakan konsep } \\
\text { dan pengaruhnya. Orientasi } \\
\text { dan kecenderungan } \\
\text { peserta didik }\end{array}$ & $\begin{array}{l}\text { Membedakan sesuatu umum yang } \\
\text { luas antara konsep-konsep dan } \\
\text { hubungannya Orientasi ke sosial. } \\
\text { Mudah dipengaruhi oleh teman } \\
\text { dan lingkungannya. }\end{array}$ & $\begin{array}{l}\text { Membedakan konsep tertentu } \\
\text { dan tumpang tindih. Orientasi } \\
\text { ke individu. Tidak mudah } \\
\text { dipengaruhi oleh teman dan } \\
\text { lingkungannya.. }\end{array}$ \\
\hline $\begin{array}{l}\text { Materi yang dibutuhkan } \\
\text { untuk dipelajari. Menyikapi } \\
\text { ketertarikan saat belajar. }\end{array}$ & $\begin{array}{l}\text { Materi dipelajari dengan konten } \\
\text { sosial, menunjukan hasil yang } \\
\text { optimal. Materi harus relevan } \\
\text { dengan pengalamannya } \\
\text { sebelumnya. }\end{array}$ & $\begin{array}{l}\text { Materi dipelajari dengan } \\
\text { konten sosial jika diperlukan. } \\
\text { Ketertarikan kepada materi } \\
\text { baru untuk kepentingannya } \\
\text { sendiri }\end{array}$ \\
\hline Menguatkan diri & Membutuhkan bantuan orang lain & $\begin{array}{l}\text { Tanpa membutuhkan bantuan } \\
\text { orang lain. }\end{array}$ \\
\hline Cara memanajemen kondisi & Perlu pengorganisasian & Bisa sendiri \\
\hline Cara menyikapi kritikan & $\begin{array}{l}\text { Gampang terpengaruh oleh } \\
\text { kritikan }\end{array}$ & $\begin{array}{l}\text { Susah dipengaruhi oleh } \\
\text { kritikan }\end{array}$ \\
\hline $\begin{array}{l}\text { Cara dan pendekatan } \\
\text { belajar yang cocok }\end{array}$ & $\begin{array}{l}\text { Pasif. Menggunakan cerama, } \\
\text { demonstrasi, membutuhkan } \\
\text { banyak petunjuk dan contoh. }\end{array}$ & $\begin{array}{l}\text { Aktif. Hanya membutuhkan } \\
\text { hipotesis untuk mengerjakan. } \\
\text { Tidak banyak petunjuk. }\end{array}$ \\
\hline Memotivasi diri & Termotivasi dari lingkungan & Termotivasi dari diri sendiri \\
\hline
\end{tabular}

Sedangkan seseorang yang memiliki gaya kognitif Field Independent (FI) yaitu seseorang dapat dengan mudah 'membagi' dari persepsi kompleks dan dengan cepat memisahkan bagian dari kesatuannya. Sedangkan menurut Sasongko \& Siswono (2013) menyatakan bahwa seseorang dengan gaya kognitif Field Independent memiliki karakteristik yang lebih melihat objek terdiri atas bagian-bagian diskrit dan terpisah dari lingkungannya dan dengan cepat mampu menganalisa untuk memisahkan elemen-elemen dari konteksnya secara lebih baik sedangkan seseorang yang memiliki gaya kognitif Field Dependent dimana karakteristik seseorang yang cenderung mengorganisasi dan mengelola informasi secara utuh mengakibatkan persepsinya cepat terpengaruh oleh perubahan lingkungannya.
Adapun menurut Garge dan Guild Fajriah \& Suseno (2016) adalah bahwa terdapat perbedaan karakteristik antara peserta didik yang memiliki gaya kognitif Field Dependent dan Field Independent yang dapat dilihat pada tabel 1.

\section{Hasil Belajar Prakarya Kewirausahaan}

Hasil belajar adalah dapat berupa nilai atau predikat berdasarkan pengetahuan siswa, keterampilan, sikap sosial dan spiritual yang didapatkan oleh siswa dalam rentang waktu tertentu setelah mendapatkan pembelajaran. Menurut Aditya (2016), hasil belajar juga dapat diartikan hasil kemampuan seseorang sesudah menjalani proses belajar. Cara mendapatkan hasil belajar bermacammacam salah satu contohnya adalah dengan memberikan soal-soal berupa soal pilihan ganda/ uraian dan tugas untuk membuat 
produk/portofolio sesuai kompetensi atau pembelajaran yang sudah didapatkan sebelumnya (pada penelitian ini menggunakan kompetensi mata pelajaran prakarya kewirausahaan kelas $\mathrm{X}$ semester genap kurikulum 2013).

Menurut Sudjana dalam Fimansyah (2015), hasil belajar yaitu suatu keahlian yang siswa dapatkan setelah siswa tersebut mendapat pengalaman belajarnya. Sedangkan menurut Supardi dalam Suhendri (2015), hasil belajar yaitu suatu bentuk perubahan kebiasaan siswa yang meliputi aspek kognitif, afektif dan atau psikomotor setelah siswa memperoleh kegiatan belajar tertentu dan level kualitas perubahannya sangat ditentukan oleh hal-hal dari dalam diri siswa tersebut dan lingkungan sosial sekelilingnya. Jadi dapat disimpulkan, hasil belajar adalah acuan terjadinya perubahan pada diri siswa yang dapat dinilai dalam bentuk angka-angka atau skor setelah diberikan tes.

Pembelajaran prakarya kewirausahaan dengan menggunakan pembelajaran langsung yaitu guru dan buku sebagai sumber belajar sudah biasa (bukan hal yang baru) membuat tidak kreatif dan cepat bosan, menjadikan tidak fokus dalam belajar dan berdampak pada hasil belajar yang tidak optimal (menunjukkan perubahan negatif) saat diberikan tugas.

Hal tersebut dapat teratasi dengan menerapkan model pembelajaran yang baru dan dirasa berbeda dari sebelumnya, dengan menerapkan pembelajaran berbasis $E$ Learning dimana tugas yang diberikan tidak terpaku pada guru dan buku namun bisa diluar itu, memberikan kebebasan/menyarankan untuk mencari referensi/sumber belajar dari internet dan memanfaatkan perangkat elektronik/ aplikasi yang lain untuk mendukung kegiatan pembelajaran dan tugas yang diberikan baik didalam atau diluar kelas dapat membangkitkan motivasi dan kreatifitas.

Merujuk dari penelitian sebelumnya bahwa menurut Wahyudi (2017), E-Learning juga bermanfaat untuk menambah sumber belajar siswa agar siswa tidak hanya memiliki acuan dari buku saja namun dari materi, animasi, video dan soal yang terdapat pada E-Learning ini. E-learning dapat dimanfaatkan untuk meningkatkan pemahaman materi dan memperluas sumber materi ajar maupun menambah aktivitas belajar serta membantu guru dalam mengefisienkan waktu pembelajaran di dalam kelas (Hanum, 2013).

Berdasarkan uraian di atas pembelajaran berbasis E-Learning sangat diperlukan dan diterapkan untuk membantu kinerja guru dan siswa lebih efektif dan efisien baik di dalam atau luar kelas, karena materi atau bahan ajar yang diberikan kepada siswa dapat berupa pemanfaatan aplikasi, animasi, text pdf, gambar, video, sumber internet, atau media elektronik yang lain. Jika siswa tidak dapat menghadiri tatap muka di kelas tidak menjadi permasalahan karena materi pelajaran tersebut dapat dibagikan dengan mudah dan siswa dapat membuka atau mempelajari kembali jika dirasa kurang jelas selama mereka inginkan, materi menjadi lebih interaktif dan menarik, merangsang kreativitas siswa dan tidak membosankan membuat siswa lebih produktif.

Perbedaan penelitian ini dari sebelumnya adalah sampel penelitian adalah 4 kelas berasal dari 2 sekolah dalam 1 kecamatan (masing-masing sekolah 2 kelas tingkat $\mathrm{X}$ ), kemudian secara acak siswa dibagi dalam kelompok eksperimen dan kontrol (menggunakan model pembelajaran E-Learning, model pembelajaran langsung), kelompok model pembelajaran E-Learning memanfaatkan media Google Classroom, PPT, text pdf, Whatsapp, Youtube, dll hasilnya dibandingkan berdasarkan gaya kognitif siswa. Penelitian ini tidak bermaksud membandingkan sekolah mana yang terbaik, karena seluruh sampel dari 2 sekolah akan digabungkan, lalu dibandingkan sesuai hasil gaya kognitif secara objektif. 
Tujuan penelitian ini adalah untuk melihat perbedaan hasil belajar prakarya kewirausahaan kelompok pembelajaran berbasis E-Learning dan langsung, melihat perbedaan hasil belajar antara gaya kognitif Field Dependent dan Field Independent, dan melihat interaksi pembelajaran berbasis ELearning, langsung, dan gaya kognitif terhadap hasil belajar.

\section{METODE}

Penelitian ini memakai desain pretestposttest non equivalent control group faktorial 2x2, dimana quasi experimental subjek kelompok siswa eksperimen dan kelompok siswa kontrol dalam penelitian ini menggunakan kelompok utuh sesuai dengan keadaan sebenarnya. Dalam penelitian ini, kelompok kontrol menerapkan pembelajaran Langsung, sedangkan kelompok eksperimen menggunakan pembelajaran berbasis E-Learning. Desain dalam penelitian dapat dilihat pada tabel 2 . Keterangan:

$A_{1}$ : Kelompok siswa dengan menggunakan Pembelajaran berbasis E-Learning

$\mathrm{A}_{2}$ : Kelompok siswa dengan menggunakan pembelajaran Langsung

$\mathrm{B}_{1} \quad$ : Kelompok siswa dengan gaya kognitif FD

$\mathrm{B}_{2} \quad$ : Kelompok siswa dengan gaya kognitif $\mathrm{FI}$

$A_{1} B_{1}$ : Kelompok siswa dengan menggunakan pembelajaran berbasis E-Learning dan dengan gaya kognitif FD
$A_{1} B_{2}$ : Kelompok siswa dengan menggunakan Pembelajaran berbasis E-Learning dan dengan gaya kognitif $\mathrm{FI}$ $A_{2} B_{1}$ : Kelompok siswa dengan menggunakan pembelajaran Langsung dan memiliki gaya kognitif FD

$\mathrm{A}_{2} \mathrm{~B}_{2}$ : Kelompok siswa dengan menggunakan pembelajaran Langsung dan memiliki gaya kognitif FI

Y : Hasil belajar mata pelajaran prakarya kewirausahaan

$\mathrm{n} \quad$ : Subjek ke- $\mathrm{n}$

Teknik sampling jenuh digunakan oleh peneliti dalam pengambilan sampel, karena seluruh anggota populasi dipakai sebagai sampel. Sampel penelitian sebanyak 120 siswa kelas X semester II tahun akademik 2019/2020 berasal dari SMAN 12 Surabaya dan SMA Wachid Hasyim 5 Surabaya. Untuk menentukan kelompok siswa kontrol dan kelompok siswa eksperimen dilakukan dengan menggunakan teknik acak.

Peneliti memakai dua instrumen pengumpulan data yaitu instrumen untuk mengukur atau mengetahui gaya kognitif siswa (Field Dependent dan Field Independent) dan instrumen untuk mengukur hasil belajar prakarya kewirausahaan. Sebelum pembelajaran siswa diberi tes berupa instrumen uji gaya kognitif group embedded figures test (GEFT) sebanyak 18 soal gambar berpola dan diberi waktu selama 20 menit mengerjakan. Siswa termasuk bergaya kognitif Field Dependent

Tabel 2. Desain Quasi Experimental Faktorial 2x2

\begin{tabular}{lcc}
\multirow{2}{*}{ Gaya Kognitif $(\mathbf{B})$} & \multicolumn{2}{c}{ Model Pembelajaran (A) } \\
\cline { 2 - 3 } & $\begin{array}{c}\text { Pembelajaran Berbasis } \\
\text { E-Learning }\left(\mathbf{A}_{\mathbf{1}}\right)\end{array}$ & $\begin{array}{c}\text { Pembelajaran } \\
\text { Langsung }\left(\mathbf{A}_{2}\right)\end{array}$ \\
\hline Field Dependent $\left(\mathrm{B}_{1}\right)$ & $\left(\mathrm{Y}_{11 \mathrm{n})}\right) \mathrm{A}_{1} \mathrm{~B}_{1}$ & $\left(\mathrm{Y}_{12 \mathrm{n})}\right) \mathrm{A}_{2} \mathrm{~B}_{1}$ \\
Field Independent $\left(\mathrm{B}_{2}\right)$ & $\left(\mathrm{Y}_{21 \mathrm{n})}\right) \mathrm{A}_{1} \mathrm{~B}_{2}$ & $\left(\mathrm{Y}_{22 \mathrm{n})}\right) \mathrm{A}_{2} \mathrm{~B}_{2}$ \\
\hline
\end{tabular}


apabila jawaban benar rentang 0-9 dan siswa dinyatakan bergaya kognitif Field Independent apabila jawaban benar rentang 10-18). Menurut Rufi'i (2011), apabila skor yang didapatkan siswa rentang 0 sampai 9 termasuk sebagai kelompok Field Dependence, dan apabila skor yang didapatkan siswa rentang 10 sampai dengan 18 termasuk sebagai kelompok Field Independent.

Setelah itu kelompok kontrol diberikan model pembelajaran Langsung dan kelompok eksperimen diberikan model pembelajaran E-Learning diakhir pembelajaran akan diberi soal-soal untuk mendapatkan hasil belajar masing-masing kelompok, hasil belajar tersebut akan diolah dengan teknik analisis Anova dua arah, melalui desain tersebut akan dibandingkan pengaruh antara model pembelajaran $E$ Learning dan model pembelajaran Langsung serta gaya kognitif Field Dependent dan Field Independent terhadap hasil belajar prakarya kewirausahaan.

\section{HASIL}

Hasil penelitian ini berisi deskripsi data pengujian hipotesis penelitian. Berdasarkan teknik analisis deskriptif Anova dua arah terdapat pembelajaran berbasis E-Learning dan pembelajaran Langsung sebagai 2 (dua) variabel bebas, sebagai variabel moderat yaitu gaya kognitif (Field Dependent dan Field Independent) dan sebagai variabel terikatnya yaitu perolehan hasil belajar prakarya kewirausahaan. Deskripsi hasil penelitian dikelompokkan seperti tabel 3.

Hasil analisis pada tabel 3 menunjukkan model pembelajaran $E$ Learning mata pelajaran prakarya kewirausahaan rata-rata nilai kelompok siswa bergaya kognitif Field Dependent sebesar ( Mean=65,38; SD=9,151) lebih kecil daripada rata-rata nilai yang dimiliki kelompok siswa bergaya kognitif Field Independent sebesar (Mean=67,23; $\mathrm{SD}=8,480$ ) sedangkan model pembelajaran Langsung rata-rata nilai kelompok siswa bergaya kognitif Field Dependent sebesar ( Mean=58,29; $S D=7,015)$ lebih kecil daripada rata-rata nilai kelompok siswa bergaya kognitif Field Independent sebesar (Mean=66,08; SD=10,962). Berdasarkan jumlah total rata-rata nilai pada model pembelajaran E-Learning sebesar (Mean=66,33; SD=8,785) lebih besar daripada rata-rata nilai kelompok siswa model pembelajaran Langsung sebesar (Mean=61,53; SD=9,605).

\section{Uji Normalitas dan Uji Homogenitas}

Setelah itu dilakukan uji normalitas One-Sample Kolmogorov-Smirnov Test dan uji homogenitas menggunakan Levene's Test of Equality of Error Variances perolehan hasil belajar mata pelajaran prakarya kewirausahaan. Hasil untuk uji normalitas dan uji homogenitas seperti tabel 4.

Tabel 3. Statistik Deskriptif Hasil Penelitian

Variabel Terikat:Hasil Belajar

\begin{tabular}{llccc}
\hline \multicolumn{1}{c}{ Pembelajaran } & \multicolumn{1}{c}{$\begin{array}{c}\text { Gaya } \\
\text { Kognitif }\end{array}$} & Rata-rata & Std. Deviasi & Jumlah Subjek \\
\hline \multirow{3}{*}{ Berbasis E-Learning } & Field Dependent & 65,38 & 9,151 & 29 \\
& Field Independent & 67,23 & 8,48 & 31 \\
& Total & 66,33 & 8,785 & 60 \\
Langsung & Field Dependent & 58,29 & 7,015 & 35 \\
& Field Independent & 66,08 & 10,962 & 25 \\
Total & Total & 61,53 & 9,605 & 60 \\
& Field Dependent & 61,5 & 8,743 & 64 \\
& Field Independent & 66,71 & 9,591 & 56 \\
& Total & 63,93 & 9,477 & 120 \\
\hline
\end{tabular}


Tabel 4. One-Sample Kolmogorov-Smirnov Test

\begin{tabular}{llr}
\hline & & Unstandardized Residual \\
\hline $\mathrm{N}$ & & 120 \\
Normal Parameters & Mean & 0 \\
& Std. Deviation & 8,85013936 \\
& Absolute & 0,122 \\
Most Extreme Differences & Positive & 0,122 \\
& Negative & $-0,081$ \\
Kolmogorov-Smirnov Z & & 1,338 \\
Asymp. Sig. (2-tailed) & & 0,056 \\
\hline
\end{tabular}

a. Test distribution is Normal.

Tabel 5. Levene's Test of Equality of Error Variances ${ }^{\mathrm{a}}$

\begin{tabular}{cccc}
\hline $\mathbf{F}$ & $\mathbf{d f 1}$ & $\mathbf{d f 2}$ & Sig. \\
\hline 2,115 & 3 & 116 & 0,102 \\
\hline
\end{tabular}

Berdasarkan tabel 4 One-Sample Kolmogorov-Smirnov Test diperoleh nilai $p=0,056>0,05$ (artinya sebaran normal), dan berdasarkan tabel 5 Levene's Test of Equality of Error Variances uji homogenitas diperoleh nilai $p=0,102>0,05$ (artinya memiliki matrik varian-kovarian sama) artinya penelitian tersebut dapat dilanjutkan untuk pengujian hipotesis. Menurut (Wardani, Made Agustia Permata, 2019) adapun kriteria pengujian adalah data dinyatakan berdistribusi normal jika nilai probabilitas (sig.) > 0,05.

Terdapat 3 hipotesis dalam penelitian ini yaitu: (Ha.1) untuk mengetahui apakah ada perbedaan hasil belajar prakarya kewirausahaan antara kelompok siswa yang menggunakan pembelajaran berbasis $E$ Learning dan Langsung, (Ha.2) untuk mengetahui apakah ada perbedaan hasil belajar prakarya kewirausahaan antara gaya kognitif Field Dependent dan gaya kognitif Field Independent, dan (Ha.3) untuk melihat apakah ada interaksi antara pembelajaran berbasis E-Learning, pembelajaran langsung, dan gaya kognitif terhadap hasil belajar prakarya kewirausahaan akan diolah dengan teknik analisis Anova dua arah dengan bantuan program SPSS 19 For Windows. Adapun hasil analisis perhitungan seperti pada tabel 6.Pada tabel 6 uji Anova dua arah diperoleh 3 keputusan: (H.1) ada perbedaan hasil belajar kelompok siswa yang menggunakan model pembelajaran $E$ -
Learning dan Langsung, dasar asumsi pengambilan keputusan yaitu jika nilai probabilitas $(p)>0,05$ maka Ho diterima artinya tidak ada perbedaan hasil belajar, sedangkan jika nilai probabilitas $(p)<0,05$ maka Ho ditolak artinya ada perbedaan hasil belajar. Oleh karenanya $F_{\text {hitung }} 6,424>$ dari $F_{\text {tabel }}$ dengan dk pembilang 1 dan penyebut 116 yaitu $3,07\left(F_{\text {hitung }}>F_{\text {tabel }}\right)$ dan $p=0,013$ maka $p<0,05$ artinya nilai rata-rata kedua populasi tidak sama sehingga terbukti bahwa hasil belajar kelompok siswa yang menggunakan pembelajaran berbasis $E$ Learning dan Langsung berbeda secara jelas dan signifikan pada taraf kepercayaan 95\%.

Hipotesis kedua (H.2) ada perbedaan hasil belajar prakarya kewirausahaan antara gaya kognitif Field Dependent dan gaya kognitif Field Independent, dasar asumsi pengambilan keputusan hipotesis jika nilai probabilitas $(p)>0,05$ maka Ho diterima artinya tidak ada perbedaan hasil belajar, sedangkan jika nilai probabilitas $(p)<0,05$ maka Ho ditolak artinya ada perbedaan hasil belajar. Oleh karenanya $F_{\text {hitung }}$ 8,795 lebih besar dari $\mathrm{F}_{\text {tabel }}$ dengan dk pembilang 1 dan penyebut 116 yaitu 3,07 ( $\left.\mathrm{F}_{\text {hitung }}>\mathrm{F}_{\text {tabel }}\right)$ dan $p=0,004$ maka $p<0,05$ artinya nilai ratarata kedua populasi tidak sama sehingga terbukti bahwa hasil belajar antara gaya kognitif Field Dependent dan gaya kognitif 
Variabel Terikat:Hasil Belajar

Tabel 6. Uji Akibat Antar Subjek

\begin{tabular}{llrrrr}
\hline \multicolumn{1}{c}{ Source } & $\begin{array}{l}\text { Type III } \\
\text { Sum of } \\
\text { Squares }\end{array}$ & df & $\begin{array}{l}\text { Mean } \\
\text { Square }\end{array}$ & F & Sig. \\
\hline Corrected Model & $1628,237^{\text {a }}$ & 3 & 542,746 & 6,95 & 0 \\
\hline Intercept & 488012,04 & 1 & 488012,04 & 6248,809 & 0 \\
\hline Model_Pembelajaran & 501,712 & 1 & 501,712 & 6,424 & 0,013 \\
\hline Gaya_Kognitif & 686,89 & 1 & 686,89 & 8,795 & 0,004 \\
\hline Model_Pembelajaran * Gaya_Kognitif & 261,441 & 1 & 261,441 & 3,348 & 0,07 \\
\hline Error & 9059,23 & 116 & 78,097 & & \\
\hline Total & 501184 & 120 & & & \\
\hline Corrected Total & 10687,467 & 119 & & & \\
\hline a. $R$ Squared $=, 152$ (Adjusted $R$ Squared $=, 130)$
\end{tabular}

Field Independent berbeda secara jelas dan signifikan pada taraf kepercayaan $95 \%$.

Hipotesis ketiga (H.3) ada interaksi antara pembelajaran E-Learning, pembelajaran Langsung, dan gaya kognitif terhadap hasil belajar prakarya kewirausahaan, dasar asumsi pengambilan keputusan hipotesis jika nilai probabilitas ( $p$ ) $>0,05$ maka Ho diterima artinya tidak ada interaksi, sedangkan jika nilai probabilitas ( $p$ ) $<0,05$ maka Ho ditolak artinya ada interaksi. Oleh karenanya $\mathrm{F}_{\text {hitung }}$ 3,348 lebih besar dari $\mathrm{F}_{\text {tabel }}$ dengan $\mathrm{dk}$ pembilang 1 dan penyebut 116 yaitu 3,07 ( $\left.\mathrm{F}_{\text {hitung }}>\mathrm{F}_{\text {tabel }}\right)$ dan $p=0,07$ maka $p>0,05$ artinya tidak ada interaksi antara pembelajaran E-Learning, pembelajaran Langsung, dan gaya kognitif terhadap hasil belajar prakarya kewirausahaan secara jelas dan signifikan pada taraf kepercayaan $95 \%$.

\section{PEMBAHASAN}

Setelah melalui langkah-langkah penelitian, hipotesis dalam penelitian ini dapat diterima dan dibuktikan dengan beberapa argumentasi, yang pertama, hasil uji analisis deskriptif Anova dua arah pada tabel 3 didapatkan nilai total rata-rata kelompok model pembelajaran E-Learning sebesar 66,33 sedangkan kelompok yang diajar dengan pembelajaran Langsung memperoleh nilai lebih rendah sebesar
61,53. Hasil uji akibat antar subjek (tabel 6) menyatakan hasil $F_{\text {hitung }}$ model pembelajaran E-Learning dan Langsung sebesar 6,424 lebih besar dari $F_{\text {tabel }}$ sebesar 3,07 atau $\left(\mathrm{F}_{\text {hitung }}>\mathrm{F}_{\text {tabel }}\right)$. Diperkuat oleh perolehan nilai signifikansi pada kolom sig. sebesar 0,013 lebih kecil daripada 0,05 artinya terbukti secara jelas bahwa model pembelajaran E-Learning dan Langsung berbeda secara jelas dan signifikan pada taraf kepercayaan 95\% telah sesuai dengan hipotesis yang diujikan dalam penelitian ini.

Hal tersebut secara garis besar membuktikan ada perbedaan rata-rata hasil belajar siswa yang diajar dengan model pembelajaran E-Learning memperoleh hasil lebih tinggi daripada kelompok yang diajar dengan pembelajaran Langsung hasilnya lebih rendah. Model pembelajaran $E$ Learning berpotensi lebih baik dalam meningkatkan perolehan hasil belajar prakarya kewirausahaan karena siswa lebih aktif dan kreatif.

Merujuk dari penelitian sebelumnya bahwa menurut Sindu et al. (2013) model pembelajaran berbasis masalah yang dikombinasikan dengan aplikasi E-Learning (E-PBL) memiliki keunggulan yang lebih baik dibandingkan dengan model pembelajaran Direct Instructions dalam hal pencapaian hasil belajar siswa (Anori, 2013). Hasil analisis data tes akhir belajar menunjukkan 
penggunaan buku ajar elektronik meningkatkan hasil belajar siswa. Menurut Ratnasari (2012), keaktifan siswa meningkat signifikan saat menggunakan E-Learning (Fatmawati, 2019) tentang adanya peningkatan partisipasi belajar E-Learning. Sistem E-Learning sesuai profil peserta didik, instrumennya tervalidasi dan mudah digunakan (Li, 2015).

Selanjutnya, berdasarkan hasil uji analisis deskriptif Anova dua arah pada tabel 3 diketahui bahwa siswa yang memiliki gaya kognitif Field Independent mendapat nilai total rata-rata sebesar 66,71 lebih besar daripada nilai total rata-rata siswa yang memiliki gaya kognitif Field Dependent sebesar 61,5. Kemudian hasil uji akibat antar subjek (tabel 6) menyatakan $F_{\text {hitung gaya }}$ kognitif sebesar 8,795 lebih besar dari $F_{\text {tabel }}$ yaitu sebesar 3,07 dimana ( $\left.F_{\text {hitung }}>F_{\text {tabel }}\right)$. Diperkuat oleh perolehan nilai signifikansi pada kolom sig. sebesar 0,004 lebih kecil daripada 0,05 artinya terbukti bahwa ada perbedaan hasil belajar prakarya kewirausahaan antara gaya kognitif Field Dependent dan gaya kognitif Field Independent berbeda secara jelas dan signifikan pada taraf kepercayaan 95\%.

Hal tersebut membuktikan bahwa ada perbedaan nilai siswa yang memiliki gaya kognitif Field Independent ternyata lebih besar/ unggul karena mudah dan cepat memahami materi, aktif, mandiri dan tidak gampang terpengaruh oleh lingkungan dibandingkan siswa yang memiliki gaya kognitif Field Dependent cenderung kurang mandiri, pasif dan gampang terpengaruh oleh lingkungan.

Hasil penelitian ini di dukung oleh López-Vargas et al. (2017) yang menyatakan siswa Field Independent memiliki perhatian selektif yang lebih besar, peserta didik dengan gaya kognitif Field Independent lebih rasional (Lu \& Lin, 2018). Menurut Yousefi (2011) kemampuan analitik FI menjadi lebih kuat. Kemampuan menganalisis merupakan kecenderungan Field Independent sedangkan sebuah pola yang konsisten pada
Field Independent dapat tampil secara signifikan lebih baik daripada Field Dependent (Suryanti, 2014).

Terakhir, hasil uji akibat antar subjek tabel 6, menunjukkan tidak ada interaksi antara pembelajaran E-Learning, pembelajaran Langsung, dan gaya kognitif terhadap hasil belajar prakarya kewirausahaan. Pembelajaran berbasis $E$ Learning dan Langsung memberi pengaruh yang berbeda terhadap hasil belajar terlepas dari tinggi rendahnya siswa dengan gaya kognitif Field Dependent. Sebaliknya siswa dengan gaya kognitif Field Independent memberi pengaruh berbeda antara perolehan hasil belajar dengan gaya kognitif Field Dependent dengan pembelajaran berbasis E-Learning dan pembelajaran Langsung.

Tidak adanya interaksi antara pembelajaran E-Learning, pembelajaran langsung, dan gaya kognitif terhadap hasil belajar prakarya kewirausahaan kemungkinan disebabkan adanya variabel kontrol diluar variabel penelitian ini seperti contoh motivasi, minat siswa dan seterusnya. Dengan demikian gaya kognitif siswa tidak ditentukan oleh model pembelajaran saja dan sebaliknya hal tersebut menunjukkan bahwa belajar adalah sesuatu yang kompleks karena dapat dipengaruhi oleh faktor yang bersifat internal (dari dalam siswa) dan eksternal (diluar siswa).

Pengembangan e-learning yang baik di era baru idealnya dirancang dengan memperhatikan karakteristik calon pengguna. Para peneliti menyebutnya dengan istilah adaptif e-learning, yakni elearning yang memiliki kemampuan untuk memfasilitasi pebelajar sesuai dengan preferensi karakteristiknya (Surahman et al., 2020; Surjono, 2011). Selain itu fitur elearning perlu diberikan teknologi cerdas sehingga dapat menampilkan progres belajar masing-masing siswa (Ulfa et al., 2019). Namun yang tidak kalah diperhatikan dari sebuah e-learning adalah kualitas pelayanan 
dari instruktur Pelayanan yang dimaksud adalah meliputi kelengkapan materi, kejelasan petunjuk tugas, dan umpan balik terhadap hasil kerja siswa. Dengan demikian terjadi interaktivitas yang optimal antara siswa dengan fasilitator.

\section{SIMPULAN}

Berdasarkan pengujian hipotesis dan pembahasan penelitian, dapat disampaikan beberapa kesimpulan hasil penelitian. Ada perbedaan hasil belajar kelompok siswa yang menggunakan model pembelajaran $E$ Learning dan Langsung, bahwa siswa yang menggunakan model pembelajaran $E$ Learning memperoleh hasil belajar yang lebih tinggi. Ada perbedaan hasil belajar prakarya kewirausahaan antara gaya kognitif Field Dependent dan gaya kognitif Field Independent, bahwa siswa dengan gaya kognitif Field Independent memiliki nilai ratarata hasil belajar lebih tinggi dibanding siswa dengan gaya kognitif Field Dependence. Tidak ada interaksi antara pembelajaran $E$ Learning, pembelajaran Langsung, dan gaya kognitif terhadap hasil belajar prakarya kewirausahaan.

Beberapa saran yang dapat disampaikan terkait dengan pemanfaatan hasil penelitian dengan mengacu pada model pembelajaran E-Learning. Guru mata pelajaran prakarya kewirausahaan disarankan menggunakan pembelajaran berbasis E-Learning untuk meningkatkan hasil belajar siswa. Secara garis besar guru dapat memanfaatkan bantuan teknologi internet dalam menerapkan proses pembelajaran kepada siswa. Pembelajaran berbasis E-Learning menawarkan kecepatan, tidak terbatasnya ruang dan waktu (siswa dapat belajar dimana dan kapan saja). Model pembelajaran E-Learning mengajak siswa untuk berperan aktif dalam mencari materi dan sumber referensi bagi dirinya, guru bukan sumber satu-satunya belajar. Model pembelajaran E-Learning murah (tidak perlu membeli buku) hanya perlu mengunduh e-book dan juga efisien (semua ada pada satu perangkat). Sebelum menerapkan model pembelajaran $E$ Learning guru wajib mempertimbangkan kebutuhan siswa dan karakter siswa, membuat tata tertib atau aturan yang jelas dan dapat dipahami oleh seluruh siswa pada saat penggunaan perangkat dan pastikan sarana dan prasarana harus dipersiapkan dengan baik.

\section{REFERENSI}

Aditya, D. Y. (2016). Pengaruh Penerapan Metode Pembelajaran Resitasi terhadap Hasil Belajar Matematika Siswa. SAP (Susunan Artikel Pendidikan), 1(2), 165174.

https://doi.org/http://dx.doi.org/10.309 98/sap.v1i2.1023

Aminoto, T. (2014). Penerapan media elearning berbasis schoology untuk meningkatkan aktivitas dan hasil belajar materi usaha dan energi di kelas xi sma $\mathrm{n}$ 10 kota jambi. Sainmatika: Jurnal Sains Dan Matematika Universitas Jambi, 8(1), 13-29.

Anori, S. (2013). Pengaruh Penggunaan Buku Ajar Elektronik Dalam Model Pembelajaran Langsung Terhadap Hasil Belajar Siswa kelas X SMAN 1 Lubuk Alung. Pillar of Physics Education, 1(1), 104-111.

https://doi.org/http://dx.doi.org/10.240 36/498171074

Cahyono, Y. D. (2015). E-learning (EDMODO) sebagai media pembelajaran sejarah. Jurnal Penelitian, 18(2), 102-115.

Chandrawati, S. R. (2010). Pemamfaatan Elearning dalam Pembelajaran. Jurnal Cakrawala Kependidikan, 8(2), 172-181.

Fajriah, N., \& Suseno, A. A. (2016). Kemampuan siswa sekolah menengah pertama dalam menyelesaikan masalah matematika berdasarkan gaya kognitif. EDU-MAT: Jurnal Pendidikan Matematika, 2(1), 15-21. https://doi.org/http://dx.doi.org/10.205 27/edumat.v2i1.584

Fatmawati, S. (2019). Efektivitas forum diskusi pada e-learning berbasis Moodle untuk meningkatkan partisipasi belajar. Refleksi 
Edukatika: Jurnal Ilmiah Kependidikan, 9(2), 210-216.

Fauzi, M. (2019). Pengaruh strategi pembelajaran swa-atur dengan discovery learning dan gaya kognitif terhadap hasil belajar Kimia. In Edcomtech Jurnal Kajian Teknologi Pendidikan (Vol. 4, Issue 1, pp. 56-66). State University of Malang (UM). https://doi.org/10.17977/um039v4i1201 9p056

Fimansyah, D. (2015). Pengaruh Strategi pembelajaran dan minat belajar terhadap hasil belajar matematika. Judika (Jurnal Pendidikan UNSIKA), 3(1), 34-44.

Hadjerrouit, S. (2010). Developing web-based learning resources in school education: $A$ user-centered approach. Interdisciplinary Journal of E-Learning and Learning Objects, 6(1), 115-135.

Hanum, N. S. (2013). Keefetifan e-learning sebagai media pembelajaran (studi evaluasi model pembelajaran e-learning SMK Telkom Sandhy Putra Purwokerto). Jurnal Pendidikan Vokasi, 3(1), 90-102. https://doi.org/https://doi.org/10.21831 /jpv.v3i1.1584

Karwati, E. (2014). Pengaruh Pembelajaran elektronik (e-learning) terhadap mutu belajar mahasiswa. Jurnal Penelitian Komunikasi, 17(1), 41-54.

Li, K. M. (2015). Learning styles and perceptions of student teachers of computer-supported collaborative learning strategy using wikis. Australasian Journal of Educational Technology, 31(1), 32-50. https://doi.org/https://doi.org/10.14742 /ajet.521

López-Vargas, O., Ibáñez-Ibáñez, J., \& RacinesPrada, O. (2017). Students' metacognition and cognitive style and their effect on cognitive load and learning achievement. Journal of Educational Technology \& Society, 20(3), 145-157.

Lu, H., \& Lin, P. (2018). A study on the effect of cognitive style in the field of STEM on collaborative learning outcome. International Journal of Information and Education Technology, 8(3), 194-198. https://doi.org/10.18178/ijiet.2018.8.3.1
032

Mashudi, M. (2016). Strategi Pembelajaran Kooperatif Tipe Jigsaw Versus Pembelajaran Langsung. UNIVERSUM: Jurnal Kelslaman Dan Kebudayaan, 10(2), 190-200.

Ngilawajan, D. A. (2013). Proses berpikir siswa SMA dalam memecahkan masalah matematika materi turunan ditinjau dari gaya kognitif field independent dan field dependent. PEDAGOGIA: Jurnal Pendidikan, 2(1), 71-83.

Pinontoan, K. F., \& Walean, M. (2020). Pengaruh Flipped Classroom Menggunakan Google Classroom Berbahan Ajar Video Tutorial Pada Mata Kuliah Kalkulus. Edcomtech, 5(2), 51-60. https://doi.org/http://dx.doi.org/10.179 77/um039v5i12020p051

Putri, N. E., Zulyadaini, Z., \& Relawati, R. (2019). Studi perbandingan pemecahan masalah matematis siswa menggunakan model pembelajaran creative problem solving (CPS) dan model pembelajaran langsung di kelas VII SMPN 6 Kota Jambi. PHI: Jurnal Pendidikan Matematika, 3(2), 91-97.

https://doi.org/http://dx.doi.org/10.330 87/phi.v3i2.72

Ratnasari, A. (2012). Studi Pengaruh Penerapan E-learning Terhadap Keaktifan Mahasiswa dalam Kegiatan Belajar Mengajar Studi Kasus Universitas Mercu Buana Jakarta. Seminar Nasional Aplikasi Teknologi Informasi (SNATI).

Rufi'i, R. (2011). Pengaruh Strategi Pembelajaran dan Gaya Kognitif terhadap Perolehan Belajar Konsep dan Prosedur Statistika.(Disertasi). DISERTASI Dan TESIS Program Pascasarjana UM.

Rusman, R. (2012). Model-model pembelajaran. Rajawali Pers.

Sasongko, D. F., \& Siswono, T. Y. E. (2013). Kreativitas Siswa dalam Pengajuan Soal Matematika Ditinjau dari Gaya Kognitif Field-Independent (FI) dan FieldDependent (FD). Jurnal Mahasiswa Teknologi Pendidikan, 2(1), 1-8.

Sindu, I. G. P., Santyasa, I. W., \& Warpala, I. W. S. (2013). Pengaruh model e-learning 
berbasis masalah dan motivasi belajar terhadap hasil belajar kkpi siswa kelas $x \mathrm{Di}$ SMK Negeri 2 Singaraja. Jurnal Teknologi Pembelajaran Indonesia, 3(1), 1-10. https://doi.org/https://doi.org/10.23887 /jtpi.v3i1.617

Suhendri, H. (2015). Pengaruh metode pembelajaran problem solving terhadap hasil belajar matematika ditinjau dari kemandirian belajar. Formatif: Jurnal IImiah Pendidikan MIPA, 3(2), 105-114. https://doi.org/http://dx.doi.org/10.309 98/formatif.v3i2.117

Surahman, E., Sulthoni, S., Ulfa, S., Husna, A., Ramdiana, H., Thaariq, Z. Z. A., Setiawan, A. B., \& Qolbi, M. S. (2020). Pelatihan Micro Learning Object Berbasis TPACK bagi Guru-Guru SMA di Garut. Abdimas Pedagogi: Jurnal Ilmiah Pengabdian Kepada Masyarakat, 3(1), 1-14.

Surjono, H. D. (2011). The design of adaptive eLearning system based on student' $s$ learning styles. International Journal of Computer Science and Information Technologies (IJCSIT), 2(5), 2350-2353.

Suryanti, N. (2014). Pengaruh Gaya Kognitif Terhadap Hasil Belajar Akuntansi Keuangan Menengah 1. Jurnal IImiah Akuntansi Dan Humanika, 4(1), 13931406.

https://doi.org/http://dx.doi.org/10.238 87/jinah.v4i1.4601

Sutanta, E. (2009). Konsep dan implementasi e-learning (studi kasus pengembangan elearning di sma $\mathrm{n} 1$ sentolo yogyakarta). Jurnal Dasi, 10(2), 1-15.

Ulfa, S., Fattawi, I., Surahman, E., \& Yusuke, H. (2019). Investigating Learners' Perception of Learning Analytics Dashboard to Improve Learning Interaction in Online Learning System. 2019 5th International Conference on Education and Technology (ICET), 49-54. https://doi.org/10.1109/ICET48172.2019 .8987229

Wahyudi, I. (2017). Pengembangan program pembelajaran fisika sma berbasis elearning dengan schoology. Jurnal IImiah Pendidikan Fisika Al-Biruni, 6(2), 187199.

https://doi.org/10.24042/jipfalbiruni.v6i 2.1850

Yousefi, M. (2011). Cognitive style and EFL learners' listening comprehension ability. Indonesian Journal of Applied Linguistics, 1(1), 73-83.

Zyainuri, Z., \& Marpanaji, E. (2012). Penerapan e-learning moodle untuk pembelajran siswa yang melaksanakan prakerin. Jurnal Pendidikan Vokasi, 2(3), 410-426. https://doi.org/https://doi.org/10.21831 /jpv.v2i3.1046 